\title{
Antibiotics on incidence of infection in neonates with meconium-stained amniotic fluid
}

\author{
M. Sholeh Kosim¹, N.P. Noerpramana ${ }^{2}$, Asril Aminullah ${ }^{3}$, Suharyo Hadisaputro ${ }^{4}$
}

\begin{abstract}
Background The effectiveness of antibiotics for preventing infection in neonates with meconium-stained amniotic fluid (MSAF) remains unclear. Not all neonates with MSAF develop meconium aspiration syndrome (MAS) or neonatal infection. Furthermore, neonatal infection diagnosis may be difficult due to lack of symptoms. As such, clinical manifestations, laboratory results, and infection markers are important for diagnosis.

Objective To evaluate antibiotic use on the incidence of infection in neonates with MSAF.

Methods This double-blind randomized controlled clinical trial was performed at Dr. Kariadi Hospital, Semarang, Indonesia from October 2009 to March 2010. Subjects were newborns with MSAF who were diagnosed by two observers (Kappa test intraobserver agreement was 0.74) and with feces metabolites found in their amniotic fluid. Sixty-nine newborns were divided into groups I and II, comprised of 35 and 34 subjects, respectively. Group I subjects (control group) were not given antibiotics, while group II subjects (treatment group) were given combination antibiotics of ampicillin $(50 \mathrm{mg} / \mathrm{kg} \mathrm{BW})$ and gentamicin $(8 \mathrm{mg} / \mathrm{kg} \mathrm{BW})$, as single doses. Neonatal infection diagnosis was based on clinical manifestations, laboratory results (leucocyte count, blood culture, and I : T ratio), and the following infection markers: procalcitonin (PCT), interleukin-6 (IL-6), tumor necrosis tumor- $\alpha$ (TNF- $\alpha$ ), and C-reactive protein (CRP). Chi-square and Fischer's exact tests were used for statistical analyses.

Results We found no significant differences in the incidence of neonatal infection between those who received and those who did not receive antibiotics, based on clinical manifestations, the first and second examination of laboratory marker $(\mathrm{P}=0.53)$, examinations of CRP, IL-6, TNF- $\alpha$, and PCT either as single markers or combinations of 2, 3, or 4 markers $(\mathrm{P}>0.05)$, as well as mortality rate $(\mathrm{P}=0.30)$.

Conclusion There is no significant difference in the incidence of infection in neonates with MSAF who received prophylactic
\end{abstract}

antibiotics compared to those who did not receive antibiotics. [Paediatr Indones. 2013;53:50-5.].

Keywords: meconium-stained amniotic fluid, antibiotic, neonatal infection markers

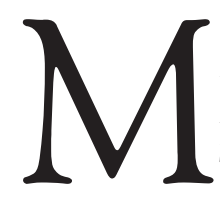
econium-stained amniotic fluid (MSAF) is a natural phenomenon occurring in pregnant mothers and their fetuses. The presence of MSAF may lead to meconium aspiration syndrome (MAS), asphyxia, and neonatal infection. Newborns with MSAF are generally managed with resuscitation, antibiotics, and nursing cares. Resuscitation and breastfeeding are considered to be standard cares, but the effectiveness of antibiotics remains unclear. Recent revisions in resuscitation

From the Department of Child Health ${ }^{1}$, Obstetrics and Gynaecology ${ }^{2}$, Diponegoro University Medical School/Dr. Kariadi Hospital, Semarang; Department of Child Health, University of Indonesia Medical School/Dr. Cipto Mangunkusumo Hospital, Jakarta ${ }^{3}$; Department of Public Health and Internal Medicine, Diponegoro University Medical School/Dr. Kariadi Hospital, Semarang ${ }^{4}$, Indonesia.

Reprint requests to: Muhammad Sholeh Kosim, Department of Child Health, Diponegoro University Medical School/Dr. Kariadi Hospital, Jalan Dr. Soetomo 16, Semarang, Indonesia. E-mail: mskosim@indosat.net.id 
M. Sholeh Kosim et al: Antibiotics on incidence of infection in neonates with meconium stained amniotic fluid

guidance for newborns with MSAF by the American Heart Association (AHA) and the American Academic of Pediatrics (AAP) recommend waiting until the newborn has been completely delivered, then assessing the child's vigor. Mucus suction for non-vigorous infants is done by laryngoscopy and an endotracheal tube. ${ }^{1} \mathrm{~A}$ multicenter study reports that intratracheal suctioning of apparently vigorous meconium-stained infants did not result in decreased incidence of respiratory distress, compared with expectant management. They observed the complication rate of intubation to be relatively low and complications to be minor and transient in nature. They recommend that endotracheal intubation and suctioning should be performed in non-vigorous infants with MSAF, or if they need positive pressure ventilation, as well as if they develop symptoms of respiratory distress subsequent to initial assessment. ${ }^{2}$

The incidence of MSAF and neonatal morbidity is higher in the presence of acute inflammation of placental membranes. The presence of meconium in the amniotic fluid should alert the physician to the potential for infection and increased neonatal morbidity. ${ }^{3}$ Approximately $13 \%$ of all live births are complicated by MSAF. Fortunately, only $5 \%$ of neonates born through MSAF develop MAS, 1,2 an estimated 25,000 to 30,000 cases and 1000 deaths related. ${ }^{4}$

Diagnosing neonatal infection is difficult due to the lack of symptoms, making clinical manifestations and laboratory findings important. Several infection markers may be used, such as CRP, IL-6, TNF- $\alpha$, and PCT. ${ }^{5-7}$

The effectiveness of antibiotics for preventing infection in neonates with MSAF has been investigated with various results. ${ }^{8}$ Antibiotics may cause anaphylaxis, lead to bacterial resistance and have other negative effects. Excessive use of antibiotics may lead to nephrotoxicity, hearing disturbances, and resistance to particular pathogens. ${ }^{9,10}$

Some hospital guidelines recommend intravenous antibiotics (penicillin and gentamicin) after consultation with a clinical microbiologist. ${ }^{11}$ The Newborn Services Clinical Guideline recommends antibiotics for non-vigorous newborns with MSAF, those with persistent symptoms of MAS, and those with other risk factors for infection. Blood cultures should be performed in these cases. ${ }^{12}$

A study concludes that holding antibiotic treatment at the onset of infection could be fatal and is not recommended, but the concomitant use of IL- 6 and CRP or TNF- $\alpha$ should allow antimicrobial treatment to be discontinued at 48 hours without waiting for microbiological results, provided that the infants are in good clinical condition. ${ }^{13}$

In Indonesia, perceptions differ on the necessity of antibiotics for newborns with MSAF. Health providers generally give antibiotics to newborns with MSAF. The discrepancy occurred in referral hospital or perinatology unit centre between giving or not giving. ${ }^{14,15}$

The objective of this study was to evaluate the effect of antibiotics on the incidence of neonatal infection in neonates with MSAF.

\section{Methods}

Subjects were neonates with MSAF who were admitted to Dr. Kariadi Hospital from October 2009 to March 2010, had birth weight of 2500-4000 grams, and had no clinical symptoms of sepsis at the time of enrollment, congenital malformations, premature maternal rupture of membranes (PROM), antenatal maternal infection, or cephalic presentation, and were delivered vaginally or by caesarian section, but not due to prolonged birth or birth dystocia. Subjects were recruited by consecutive sampling. Diagnoses of MSAF were determined by two clinicians (Kappa test intraobserver agreement 0.74 ) and amniotic fluid contained one fecal metabolite. Study design was double-blind, randomized, controlled trial. Randomization by block allocation was done by pharmacy staff. Group I (control group) did not receive antibiotics, while group II (experimental group) received $50 \mathrm{mg} / \mathrm{kg} \mathrm{BW}$ ampicillin and $8 \mathrm{mg} /$ $\mathrm{kg} \mathrm{BW}$ gentamicin in a single dose. Both groups were given standard management. Examination done firstly as the subject dicided to be the subject usually at birth and secondly on day $3-5$. The incidence of neonatal infection was made by clinical manifestations, laboratory findings (leucocyte count, blood culture and I : T ratio), and infection markers including PCT, IL-6, TNF- $\alpha$, and CRP, singly or combined as 2, 3, or 4 markers. Previously determined cut off points for the infection markers were as follows: CRP $>10 \mathrm{mg} / \mathrm{L}$, PCT $>1 \mathrm{ng} / \mathrm{mL}$, IL- $6>44.4 \mathrm{pg} / \mathrm{m}$, and TNF- $\alpha>41 \mathrm{pg} / \mathrm{m} .{ }^{16-18}$ Chi- 
square test and Fischer's exact test were used for statistical analyses.

\section{Results}

Subjects were 69 neonates consisting of 35 subjects in group I and 34 subjects in group II. Subjects' characteristics were recorded, including birth weight, birth length, gestational period, and type of delivery (Table 1).

There was no significant difference in mean birth weight, gestational period and type of delivery

Table 1. Subjects characteristics

\begin{tabular}{|c|c|c|}
\hline Characteristics & $\begin{array}{c}\text { Group I } \\
\mathrm{n}=35\end{array}$ & $\underset{n=34}{\text { Group II }}$ \\
\hline Mean birth weight (SD), gram & 2900 (572.32) & $3000(522.80)$ \\
\hline Mean length at birth (SD), $\mathrm{cm}$ & $48 \quad(1.80)$ & $49 \quad(2.09)$ \\
\hline \multicolumn{3}{|l|}{ Sex, $\mathrm{n}$} \\
\hline Male & 16 & 22 \\
\hline Female & 19 & 12 \\
\hline \multicolumn{3}{|l|}{ Gestasional age, $n$} \\
\hline$>41$ weeks & 9 & 10 \\
\hline 37- 41 weeks & 26 & 24 \\
\hline \multicolumn{3}{|l|}{ Type of delivery, $n$} \\
\hline Vaginal delivery & 11 & 10 \\
\hline Caesarean section & 24 & 24 \\
\hline \multicolumn{3}{|l|}{ Apgar score $5^{\text {th }}$ minute, $n$} \\
\hline $7-10$ & 29 & 25 \\
\hline$<7$ & 6 & 9 \\
\hline
\end{tabular}

Table 2. Incidence of neonatal infection based on clinical manifestations and laboratory findings

\begin{tabular}{lccc}
\hline $\begin{array}{c}\text { Incidence of } \\
\text { neonatal infection }\end{array}$ & $\begin{array}{c}\text { Group I } \\
\mathrm{n}=35\end{array}$ & $\begin{array}{c}\text { Group II } \\
\mathrm{n}=34\end{array}$ & P value \\
\hline Infection (+) & 8 & 10 & $0.530^{* *}$ \\
Infection (-) & 27 & 24 & \\
\hline${ }^{* *}$ Chi-square test & & &
\end{tabular}

between the two groups, as well as on mean length at birth.

Neonatal infection diagnoses were based on clinical manifestations, laboratory findings and infection markers. Table 2 shows that the incidence of neonatal infection based on clinical manifestations and laboratory findings was not significantly different between groups I and II $(\mathrm{P}=0.53)$, with similar proportion in incidence, $8 / 35$ and $10 / 35$, respectively.

Single infection marker examinations were used to confirm the diagnosis of neonatal infection as shown in Table 3. There was no significant differences in the percentage of single positive infection markers between the groups in either the first or second examination.

Examinations of 2 marker-combination were done and the results are shown in Table 4.

Examinations of 3 marker-combination were done concurrently to confirm neonatal infection, as shown in Table 5. There was no significant differences in the incidence of neonatal infections between the two groups in the first and second examinations.

We also performed a 4 marker-combination examination in order to confirm the incidence of neonatal infection, as shown in Table 6. The incidence of neonatal infection between the two groups based on the combination of 4 markers (CRP, IL-6, TNF- $\alpha$, and PCT) was not significantly different in the first exam $(\mathrm{P}=0.746)$, nor in the second exam $(\mathrm{P}=0.169)$.

Subjects' mortality is shown in Table 7. At the time of hospital discharge, the number of survivors was not significantly different in the two groups $(\mathrm{P}=0.300)$. Neonatal death occurred in 4 cases, 1 from group I and 3 from group II. Meconium aspiration syndrome was suspected as the cause of death in 2 cases, 1 in group I and 1 in Group II.

Table 3. The incidence of infection based on single marker examinations between groups in the two examinations.

\begin{tabular}{|c|c|c|c|c|c|c|c|c|c|c|}
\hline \multirow{3}{*}{ Markers } & \multirow{2}{*}{\multicolumn{2}{|c|}{$\begin{array}{c}\text { Group I } \\
1^{\text {st }} \text { exam }\end{array}$}} & \multirow{2}{*}{\multicolumn{2}{|c|}{$\begin{array}{l}\text { Group II } \\
1^{\text {st }} \text { exam }\end{array}$}} & \multirow{3}{*}{$P$ value } & \multicolumn{2}{|c|}{ Group I } & \multicolumn{2}{|c|}{ Group II } & \multirow{3}{*}{$P$ value } \\
\hline & & & & & & & $\mathrm{am}$ & & $\mathrm{am}$ & \\
\hline & \multicolumn{2}{|c|}{ Infection (+) } & \multicolumn{2}{|c|}{ Infection (+) } & & \multicolumn{2}{|c|}{ Infection (+) } & \multicolumn{2}{|c|}{ Infection (+) } & \\
\hline CRP, n (\%) & 1 & (3) & 1 & (3) & $0.746^{*}$ & 1 & (3) & 4 & (12) & $0.170^{\star *}$ \\
\hline IL-6, n (\%) & 14 & (40) & 21 & (62) & $0.070^{* *}$ & 12 & (34) & 13 & (38) & $0.730^{\star *}$ \\
\hline TNF- $\alpha, \mathrm{n}(\%)$ & 1 & (3) & 1 & (3) & $0.746^{\star}$ & 2 & (6) & 7 & (21) & $0.070^{* *}$ \\
\hline PCT, n (\%) & 12 & (34) & 11 & (32) & $0.870^{* *}$ & 11 & (46) & 16 & (47) & $0.180^{* *}$ \\
\hline
\end{tabular}

${ }^{*}$ Fischer's exact test; ${ }^{* *}$ Chi-square test 
M. Sholeh Kosim et al: Antibiotics on incidence of infection in neonates with meconium stained amniotic fluid

Table 4. The incidence of infection based on 2 marker-combination examinations between the two groups in the first and second examinations

\begin{tabular}{|c|c|c|c|c|c|c|c|c|c|c|}
\hline \multirow[t]{2}{*}{ Markers } & \multicolumn{2}{|c|}{$\begin{array}{l}\text { Group I } \\
1^{\text {st }} \text { exam }\end{array}$} & \multicolumn{2}{|c|}{ Group II } & \multirow{2}{*}{$P$ value } & \multicolumn{2}{|c|}{ Group I } & \multicolumn{2}{|c|}{ Group II $2^{\text {nd }}$} & \multirow{2}{*}{$P$ value } \\
\hline & \multicolumn{2}{|c|}{ Infection (+) } & \multicolumn{2}{|c|}{ Infection (+) } & & \multicolumn{2}{|c|}{ Infection (+) } & \multicolumn{2}{|c|}{ Infection (+) } & \\
\hline CRP and IL-6, n (\%) & 1 & (3) & 1 & (3) & $0.746^{*}$ & 1 & (3) & 4 & (12) & $0.170^{*}$ \\
\hline CRP and TNF- $\alpha, n(\%)$ & 1 & (3) & 1 & (3) & $0.746^{*}$ & 1 & (3) & 4 & (12) & 0.169 \\
\hline CRP and PCT, n (\%) & 1 & (3) & 1 & (3) & $0.746^{*}$ & 1 & (3) & 4 & (12) & 0.169 \\
\hline IL-6 and TNF- $\alpha, \mathrm{n}(\%)$ & 1 & (3) & 1 & (3) & $0.746^{*}$ & 1 & (3) & 7 & (21) & $0.020^{*}$ \\
\hline IL-6 and PCT, n (\%) & 8 & (23) & 10 & (29) & $0.530^{* *}$ & 4 & (11) & 10 & (29) & $0.060^{*}$ \\
\hline TNF- $\alpha$ and PCT, n (\%) & 1 & (3) & 1 & (3) & $0.746^{\star}$ & 1 & (3) & 6 & (18) & $0.049^{*}$ \\
\hline
\end{tabular}

${ }^{*}$ Fischer's exact test; ${ }^{* *}$ Chi-square test

Table 5. The incidence of infection based on combined 3 markers examination between the two groups in the first and second examinations

\begin{tabular}{|c|c|c|c|c|c|c|}
\hline \multirow[t]{2}{*}{ Markers } & $\begin{array}{l}\text { Group I } \\
1^{\text {st }} \text { exam }\end{array}$ & $\begin{array}{l}\text { Group II } 1^{\text {st }} \\
\text { exam } \\
\end{array}$ & \multirow[t]{2}{*}{$P$ value } & $\begin{array}{c}\text { Group I } \\
2^{\text {nd }} \text { exam }\end{array}$ & $\begin{array}{c}\text { Group II } \\
2^{\text {nd }} \text { exam } \\
\end{array}$ & \multirow[t]{2}{*}{$P$ value } \\
\hline & Infection (+) & Infection (+) & & Infection (+) & Infection (+) & \\
\hline CRP, IL-6 and TNF- $\alpha, n(\%)$ & $1(3)$ & $1(3)$ & $0.746^{*}$ & $1(3)$ & $1(3)$ & $0.746^{*}$ \\
\hline CRP, IL-6 and PCT, n (\%) & $1(3)$ & $1(3)$ & $0.746^{*}$ & $1(3)$ & $4(12)$ & $0.169^{*}$ \\
\hline CRP, TNF- $\alpha$ and PCT, n (\%) & $1(3)$ & $1(3)$ & $0.746^{*}$ & $1(3)$ & $4(12)$ & $0.169^{*}$ \\
\hline IL-6, TNF- $\alpha$ and PCT, n (\%) & $1(3)$ & $1(3)$ & $0.746^{*}$ & $1(3)$ & $5(15)$ & $0.090^{*}$ \\
\hline
\end{tabular}

${ }^{*}$ Fischer's exact test

Table 6. The incidence of infection based on a 4 marker-combination between the two groups in the first and second examinations

\begin{tabular}{|c|c|c|c|c|c|c|}
\hline \multirow[t]{2}{*}{ Markers } & $\begin{array}{c}\text { Group I } \\
1^{\text {st }} \text { exam }\end{array}$ & $\begin{array}{l}\text { Group II } \\
1^{\text {st }} \text { exam }\end{array}$ & \multirow{2}{*}{$P$ value } & $\begin{array}{c}\text { Group I } \\
2^{\text {nd }} \text { exam } \\
\end{array}$ & $\begin{array}{c}\text { Group II } \\
2^{\text {nd }} \text { exam } \\
\end{array}$ & \multirow[t]{2}{*}{$P$ value } \\
\hline & Infection (+) & Infection (+) & & Infection (+) & Infection (+) & \\
\hline CRP, IL-6, TNF- $\alpha$ and PCT, n (\%) & $1(3)$ & $1(3)$ & 0.746 & $1(3)$ & $4(11)$ & $0.169^{*}$ \\
\hline
\end{tabular}

${ }^{*}$ Fischer's exact test

Table 7. Survival in the two groups

\begin{tabular}{lccc}
\hline Condition & Group I & Group II & P value \\
\hline Died, $\mathrm{n}(\%)$ & $1(3)$ & $3(9)$ & $0.300^{*}$ \\
Survived, $\mathrm{n}(\%)$ & $34(97)$ & $31(91)$ & \\
\hline
\end{tabular}

*Fischer's exact test

\section{Discussion}

The objective of this study was to evaluate the effect of antibiotics on the incidence of infection in neonates with MSAF. We found no significant difference in the incidence of infection in neonates who received antibiotics compared to those who did not receive antibiotics. We observed that neonates who did not receive antibiotics were not more likely to develop an infection, based on clinical criteria and laboratory findings. Using clinical manifestations, laboratory findings, and the results of two examinations of 4 infection markers (PCT, IL-6, TNF- $\alpha$, and CRP), we found that the use of antibiotics did not make a significant difference in infection incidence. Besides, the number of survivors were similar in the two groups.

Diagnostic markers are valuable as indicators of neonatal infection. Serial measurement of these markers may increase diagnostic sensitivity, and the use of a variety of markers may increase diagnostic accuracy. Past studies showed that these markers may be valuable for consideration of stopping antibiotic treatment earlier, but to date there is no diagnostic test to replace clinical judgement for continuing antibiotic treatment early on in cases of suspected neonatal infection. $6,7,16,17$

Infection diagnosis based on a single marker should not be done, since no single ideal marker has been identified to confirm a diagnosis of infection. $5,17,18$ 
Therefore, in our study we used combinations of markers, in which levels at a higher than cut off point were defined as indicating the presence of neonatal infection.

In our study, the incidence of infection based on 2 marker-combination examinations IL- 6 and TNF- $\alpha$, in the second examination is significantly different $(\mathrm{P}=0.020)$, but the other markers were seen not significantly different and the incidence of infection based on a 4 marker-combination in the Group II in the second examination were 4 babies became infection, that means another 3 babies who were not infected in the first examination became infected in the second examination, but these were not significantly different

Similar to our findings, a retrospective study from Yogyakarta reported that neonates with potential infections who received prophylactic antibiotics for prevention of clinical early neonatal sepsis had outcomes similar to those who did not receive antibiotics. ${ }^{19}$

A Thai study on the efficacy and side effects of prophylactic antibiotics for MSAF during labor to prevent maternal and neonatal infections concluded that compared to placebo, antibiotics during labor may reduce chorioamnionitis. However, there was no evidence that antibiotics reduced postpartum endometritis, neonatal sepsis, or NICU admission. This systematic review revealed the need for better-designed, adequately powered randomized, controlled trials to assess the effect of prophylactic antibiotics on the incidence of maternal and neonatal complications. ${ }^{20}$

Our study was performed in a teaching hospital setting with facilities not available in primary health centers. A limitation of our study was not investigating anti-inflammatory cytokine levels. Cytokine levels may have explained why neonates with MSAF who did not receive antibiotics did not have infection, and could be a subject of further study.

We find no significant difference in the incidence of neonatal infection between neonates with MSAF who did not receive antibiotics compared to those who did receive antibiotics. Also, increased levels of PCT, IL-6, TNF-a, and CRP in neonates with MSAF who did not receive antibiotics is not significantly different from those who received antibiotics, whether analyzed singly or in combinations of 2, 3, or 4 markers.
Based on our findings, we propose that prophylactic antibiotic use in newborns with MSAF is not required. As such, these patients should be under clinical observation and laboratory examinations should be performed until a diagnosis of neonatal infection is confirmed. The examination of hematologic parameters [leukocyte count, platelet count, blood smear for toxic granulation and immature to total neutrophil ratio (I : T ratio)] available in most health facilities, as well as levels of at least 2 infection markers in neonates with MSAF at risk factor for infection should be performed. Further study should include observational, prospective cohort comparisons as part of a large, communitybased study and testing anti-inflammatory cytokines in neonates with MSAF.

\section{References}

1. American Heart Association \& American Academy of Pediatrics. Lesson 1. In: Kattwinkel J, Short J, editors. Textbook of neonatal resuscitation. $5^{\text {th }}$ ed. American Academy of Pediatrics. 2006. pp. 9-11.

2. Wiswell TE, Gannon CM, Jacob J, Goldsmith L, Szyld E, Weiss K, et al. Delivery room management of the apparently vigorous meconium-stained neonate: results of the multicenter, international collaborative trial. Pediatrics. 2000;105:1-7.

3. Rao S, Pavlova Z, Incerpi MH, Ramanathan R. Meconiumstained amniotic fluid and neonatal morbidity in near-term and term deliveries with acute histologic chorioamnionitis and/or funisitis. J Perinatol. 2001;21:537-40.

4. Gelfand SL, Fanaroff JM, Walsh MC. Meconium stained fluid: approach to the mother and the baby. Pediatr Clin N Am. 2004;51:655-67.

5. Hatherill M, Tibby SM, Syke K, Turner C, Mur IA. Diagnostic markers of infection: comparison of procalcitonin with C-reactive protein and leukocyte count. Arch Dis Child. 1999;81:417-21.

6. Benitz WE, Han MY, Madan A, Ramachandra P. Serial serum C-reactive protein levels in the diagnosis of neonatal infection. Pediatrics. 1998;102:E41.

7. Okazaki K, Kondo M, Kato M, Kakinuma R, Nishida A, Noda M, et al. Serum cytokine and chemokine profiles in neonates with meconium aspiration syndrome. Pediatrics. 2008;121:748-53.

8. Shivananda S, Murthy P, Shah PS. Antibiotics for neonates born through meconium stained amniotic fluid. Cochrane 
M. Sholeh Kosim et al: Antibiotics on incidence of infection in neonates with meconium stained amniotic fluid

Database of Systematic Reviews 2006, Issue 4. Art. No: CD006183. DOI: 10.1002/14651858.CD006183.

9. Mudd PA. Ototoxicity. Medscape Reference [cited January 2013]. Available from: http://emedicine.medscape.com/ article/857679-overview

10. McCracken GH Jr. Aminoglycoside toxicity in infants and children. Am J Med. 1986;80:172-8.

11. BUPA Cromwell Hospital. Neonatal unit antibiotic guidelines. 2010 [cited January 2013]. Available from: http://www. infectioncontrolservices.co.uk/documents/cromwell/antibiotics/ Neonatal_Unit_Antibiotic_Guidelines_Sept_2009.pdf

12. Newborn Services Clinical Guideline. Meconium-stained liquor and meconium aspiration. 2004 [cited April 2008]. Available from: http://www.adhb.govt.nz/newborn/Guidelines/ Admission/MeconiumStainedLiquorAndMAS.htm

13. $\mathrm{P} \mathrm{Ng}, \mathrm{S}$ Cheng, $\mathrm{K}$ Chui, $\mathrm{T}$ Fok, $\mathrm{M}$ Wong, W Wong, et al. Diagnosis of late onset neonatal sepsis with cytokines, adhesion molecule, and C-reactive protein in preterm very low birthweight infants. Arch Dis Child Fetal Neonatal Ed. 1997;77:F221-7.

14. Dasa Tjipt G, Azlin E, Sianturi P, Lubis BG. Gawat Napas pada neonatus. [cited $2012 \mathrm{March}$ ]. Available from: www. ocw.usu.ac.id.ka_slide gawat napas pada neonatus.pdf

15. Askep kapukonline.com. Askep asuhan keperawatan aspirasi mekonium anak. [cited 2010 January]. Available from: $h t t p: / /$ www.kapukonline.com/2010/03/askepaspirasimekoniumanak.htm

16. Ng PC. Diagnostic markers of infection in neonates. Arch Dis Child Fetal Neonatal Ed. 2004;89:F229-35.

17. Chiesa C, Panero A, Rossi N, Stegagno M, De Giusti M, Osborn JF, et al. Reliability of procalcitonin concentrations for the diagnosis of sepsis in critically neonates. Clin Infect Dis. 1998;26:664-72.

18. Ratanakorn W, Srijariya W, Chamnanvanaki S, Saengaroon P. Incidence of neonatal infection in newborn infants with a maternal history of premature rupture of membranes (PROM) for 18 hours or longer by using Phramongkutklao Hospital Clinical Practice Guideline (CPG). J Med Assoc Thai. 2005;88:973-8.

19. Darmawati T, Surjono A, Wandita S. Evaluasi antibiotik profileksi pada neonatus dengan potensial terinfeksi terhadap kejadian sepsis neonatorum klinis dini di RS. Dr. Sardjito, Yogyakarta. B.I.Ked. 2001;33:131-7.

20. Siriwachirachai T, Sangkomkamhang US, Lumbiganon P, Laopaiboon M. Antibiotics for meconium-stained amniotic fluid in labour for preventing maternal and neonatal infections. Cochrane Database of Systematic Reviews 2010, Issue 12. Art. No.: CD007772. DOI: 10.1002/14651858. CD007772.pub2. 